УДК 332.1:631.14:637.12

DOI: https://doi.org/10.37320/2415-3583/21.9

Кравченко М.В.

доктор економічних наук, доцент кафедри обліку, оподаткування та управління фінансово-економічною безпекою Дніпровський державний аграрно-економічний університет ORCID: https://orcid.org/0000-0002-6942-0914

\title{
ЦІЛЬОВІ УСТАНОВКИ УПРАВЛІННЯ \\ ІНВЕСТИЦІЙНО-ІННОВАЦІЙНОЮ ДІЯЛЬНІСТЮ ДНІПРОПЕТРОВСЬКОЇ ОБЛАСНОЇ ДЕРЖАВНОЇ АДМІНІСТРАЦІЇ ЩОДО ЗАБЕЗПЕЧЕННЯ ЕКОНОМІЧНОЇ БЕЗПЕКИ АГРАРНОГО СЕКТОРУ РЕГІОНУ В УМОВАХ ДЕЦЕНТРАЛІЗАЦІЇ
}

\begin{abstract}
У статті обгрунтовано теоретико-методичні і практичні положення, спрямовані на ичільові установки управління інвестиційно-інноваційною діяльністю Дніпропетровської обласної державної адміністрації щзодо забезпечення економічної безпеки регіону в умовах децентралізації. Відповідно до зазначеного, розглянуто теоретико-методичні аспекти інвестиційно-інноваційної діяльності обласної державної адміністрації щзодо формування інфраструктури регіону в умовах децентралізації; проаналізовано сучасний стан залучення інвестицій у розвиток інфраструктури регіону; виділено завдання та заходи залучення інвестицій у формування інфраструктури регіону; визначено перспективи залучення інвестицій у розвиток інфраструктури регіону; обтрунтовано цільові установки управління інвестищійно-інноваційною діяльністю обласної державної адміністрації щодо формування інфраструктури регіону в умовах дещентралізації; запропоновано державно-приватне партнерство як інструмент залучення інвестицій у розвиток інфраструктури регіонів; визначено механізми забезпечення розвитку інноваційних процесів щุодо формування інфраструктури регіону.
\end{abstract}

Ключові слова: інвестиції, інновачії, економічна безпека, стратегія, регіон, інтеграція, аграрний сектор.

Постановка проблеми. Стан інфраструктурної сфери регіонів як сукупність об'єктів економічної та соціальної інфраструктури, що розташовані на території регіону і забезпечують безперебійне й ефективне функціонування регіональної економіки у цілому i життєдіяльності людей зокрема, чинить істотний вплив на конкурентоспроможність регіональної економіки. Окрім того, рівень розвитку інфраструктури зумовлює передумови, швидкість і якість переходу країн та регіонів у новий технологічний уклад. Відсутність розвинених і ефективно функціонуючих об'єктів інфраструктури в регіонах призводить до істотного стримування можливостей зниження собівартості, зростання транзакційних витрат суб'єктів господарювання та обмежує можливості залучення інвестицій у регіональну економіку.

Розвиток інфраструктурної сфери регіонів знаходиться у прямій залежності від обсягів та інтенсивності залучення в неї інвестицій. При цьому в силу значної капіталомісткості, ризикованості та тривалості строків окупності приватний капітал, як правило, дуже обережно включається в реалізацію інфраструктурних проєктів. 3 іншого боку, обмеженість бюджетних ресурсів переважної більшості регіонів України, а також проблеми, пов'язані з якістю державного управління на регіональному та муніципальному рівнях під час реалізації складних інноваційних проєктів в інфраструктурній сфері, стримують можливості вирішення багатьох принципових регіональних соціально-економічних питань. У результаті відбувається істотне зниження темпів розвитку інфраструктурної сфери регіонів. Останнє, своєю чергою, об'єктивно веде до уповільнення зростання конкурентоспроможності регіонів і країни у цілому, а також створює передумови для виштовхування їі на периферію світової економіки $[1$, c. $7-10]$.

Аналіз останніх досліджень і публікацій. Значний внесок у розвиток теоретичних і практичних аспектів регіональної інвестиційно-інноваційної політики щодо формування інфраструктури регіону зробили такі вітчизняні вчені: О.Р. Бахматюк, О.В. Дегтярьов, К.С. Жадько, З.Б. Живко, С.Н. Ілляшенко, Н.І. Ільяш, А.Б. Качинський, Г.В. Козаченко, В.І. Криленко, Н.О. Кулагіна, В.І. Куценко, Е.М. Лібанова, М.В. Лучик, О.М. Ляшенко, М.В. Місюк, Г.М. Рябенко, О.В. Сарафін, А.Г. Свєтлаков, Г.П. Ситник, В.П. Удовиченко, В.І. Франчук, А.В. Череп, О.В. Шубравська, Г.О. Комарницька, Т.А. Комашенко, І.А. Косач, М.Ю. Куриляк, Г.В. Лещук, М.П. Мартьянов, Л.О. Омельянович, О.Ю. Руденко, В.Г. Федоренко, Д.В. Фірсов та ін.

Разом із тим питання організації, методики і практики процесу управління інвестиційно-інноваційною діяльністю Дніпропетровської обласної державної адміністрації щодо забезпечення економічної безпеки регіону в умовах децентралізації $\epsilon$ невирішеним. Багато теоретичних розробок досі не застосовуються в практичній діяльності. Дискусійними залишаються питання сутності та змісту інвестиційної діяльності обласної державної адміністрації, питання щодо формування організаційно-економічних механізмів забезпечення управління інвестиційно-інноваційною діяльністю Дніпропетровської обласної державної адміністрації щодо забезпечення економічної безпеки регіону в умовах децентралізації. 
Також генезис та зміцнення економічної безпеки даного сектору економіки у своїх працях висвітлювали Aleksy Kwilinski, K. Pajak, F. Stewart, Ph. Kotler, M. Porter, J. Shumpeter, Z. Stachowiak, B. Verrier, B. Rose, M. Zhou.

Мета статті полягає в обгрунтуванні теоретикометодичних і практичних положень, спрямованих на цільові установки управління інвестиційно-інноваційною діяльністю Дніпропетровської обласної державної адміністрації щодо забезпечення економічної безпеки регіону в умовах децентралізації.

Виклад основного матеріалу. Як уже відзначалося раніше, стратегія інноваційного розвитку країни та ії регіонів визначає як один із пріоритетних напрямів створення сприятливих умов для платників податків, зайнятих в інноваційних сферах виробництва.

Регіоналізація та децентралізація стали ключовими принципами світової політики на історичному етапі. Це ознаменувало початок фази модернізації вітчизняної соціально-економічної системи та вплинуло на зростаючу важливість багаторівневого управління та різкі зміни в регіональному управлінні. Процеси децентралізації, які відбуваються в більшості європейських країн, супроводжуються введенням і реалізацією принципів досконалого управління під впливом європейської регіональної політики.

У європейських країнах децентралізація відіграє важливу роль у побудові принципів соціально-економічного розвитку. Сучасна тенденція до ліквідації кордонів європейських країн базується на об'єднанні сильної транснаціональної коаліції. Це дає поштовх до виникнення політичних та географічних моделей, у яких процес національної єдності включає фрагментацію власних територій та новий розвиток ідентичностей у регіонах, які представляють ці нації. Розмивається «серединний» рівень окремих країн, і на перший план виходять, з одного боку, наднаціональні структури і механізми, а з іншого - його «атоми» - регіони. Саме регіональні осередки перетворюються на основні ланки європейського політичного простору, формуючи так звану «Європу регіонів».

Світовий досвід показав, що для ефективного вирішення регіональних проблем та підтримки їхнього розвитку необхідні законодавча інтеграція та впровадження системи цілеспрямованих заходів для сприяння регіональному розвитку на національному рівні. Тому стимулювання регіональної політики в усіх країнах Європейського Союзу, як правило, регулюється відповідними законами у зв'язку із заходами СС. У деяких країнах (Італія, Німеччина, Іспанія) основна мета регіональної політики викладена в конституціях.

Проблеми активізації інвестиційно-інноваційної діяльності і модернізації економіки країни та їі регіонів мають системний характер і стосуються всіх регіонів, всіх галузей і сфер діяльності. Зацікавленість роль регіонів в активізації інвестиційної діяльності 3 кожним роком зростає, і для стимулювання інвестиційної активності на регіональному рівні робиться чимало зусиль, що сприяють формуванню сприятливого інвестиційного клімату та інвестиційної привабливості території. У зв'язку з наявністю складного завдання - формування стимулів переходу національної економіки із сировинного на інноваційний шлях розвитку, а так само створення максимально можливої кількості конкурентоспроможних підприємств світового рівня - недостатньо тих зусиль, які робляться як на державному, так і на регіональному рівні. Необхідні кардинально нові заходи та ідеї, спрямовані на зростання інвестиційного потенціалу, зниження інвестиційних ризиків національної економіки і збільшення припливу інвестицій в національну економіку. Причому зміни повинні торкнутися не лише податкового, адміністративного, процесуального та кримінального законодавства, а й бюджетного федералізму. Особливої уваги, на думку керівництва країни, заслуговують будівництво в регіонах автомобільних доріг, високошвидкісних залізничних магістралей, розвиток місцевих авіаліній, які сьогодні знаходяться в поганому стані. Розвинена транспортна інфраструктура відіграє важливу роль у залученні інвестицій, вПливає на трудову мобільність і рівень організації бізнесу.

Важливим завданням розвитку регіонів є підвищення їхньої інвестиційної привабливості, що має сприяти соціально-економічному процвітанню як кожного 3 них, так і країни у цілому. Інвестиційна привабливість регіону може знаходити свій вираз у формуванні інвестиційного клімату - сукупності політичних, економічних, соціальних і юридичних умов, що сприяють інвестиційному процесу, рівних для вітчизняних та іноземних інвесторів, однакових за привабливістю для вкладення в національну економіку [2, с. 13-21].

Додамо також, що важливою конкурентною перевагою під час залучення інвестицій у регіони, критерієм оцінки діяльності органів виконавчої влади регіонального та місцевого рівнів є якість територіального менеджменту.

Іншими словами, у тому чи іншому регіоні необхідно створити такі умови, щоб він став сприйматися потенційними інвесторами як найпривабливіше місце для вкладення інвестицій. У зв'язку із цим територіальним органам влади необхідно шукати відповіді на такі питання:

- які напрями діяльності найбільше потребують інвестицій;

- які форми інвестицій кращі;

- що необхідно зробити для підвищення інвестиційної привабливості регіону.

Іміджева стратегія кожного регіону індивідуальна. Багато що визначається загальними завданнями соціально-економічного розвитку. Але разом із тим ми маємо справу з певною методологією і комунікативними інструментами. Розроблення тієї чи іншої моделі іміджевої стратегії спирається на вирішення таких завдань:

- формування позитивного іміджу регіону, привабливого для інвесторів;

- інформування цільових аудиторій про розвиток інфраструктури для здійснення ділової активності в регіоні;

- розроблення системи антикризових комунікацій.

Для забезпечення економічного зростання регіону в подальшому необхідний комплексний підхід до проблеми залучення інвестиційних ресурсів і переходу до виконання інвестиційної діяльності господарюючих суб'єктів. Першочергово необхідний аналіз джерел 
потенційних інвестицій, правдива оцінка реальних можливостей їх мобілізації i шляхів ефективності залучає інвестиції.

До складу інвестиційного потенціалу регіону включаються вісім приватних потенціалів: ресурсно-сировинний, виробничий, споживчий, інфраструктурний, інноваційний (ураховує комплекс науково-технічної діяльності в регіоні), трудовий (використовує чисельність і освітній рівень економіки), інституційний (рівень інституційного розвитку в регіоні) і фінансовий (сукупність грошових надходжень у бюджетну систему). Таким чином, можна констатувати, що інвестиційна привабливість регіонів пов'язана зі: споживчим потенціалом; схвальними кліматичними умовами; рівнем адміністративної підтримки інвестора, надійністю і вартістю енергозабезпечення; стабільним соціальнополітичним становищем; розвитком водопостачання, енергопостачання, телекомунікації тощо); рівнем розвитку фінансової та страхової інфраструктури; створенням особливих економічних зон.

Виявлені тенденції формування платформи управління інвестиційною привабливістю регіону за допомогою формування точок зростання 3 урахуванням пріоритетного типу реалізованих інновацій та регіонального регулювання інноваційної активності суб'єктів господарювання, що реалізуються в рамках концепції регіону як квазідержави, показують, що кожному підтипу управління відповідають різні цільові установки, що визначають поступальну динаміку регіону. При цьому одними 3 ключових чинників, що впливають на вибір методу регіонального управління інвестиційною привабливістю, є поточний стан i перспективи розвитку інституційного середовища мезорівневої соціально-економічної системи, а також сформовані напрями реалізації регіональної інвестиційно-інноваційної політики (табл. 1).

Становлення регіонів країни невіддільне від розвитку науки, від сукупного інноваційного потенціалу, своєчасного його розвитку і використання в інтересах усього суспільства, що передбачає створення інноваційної економіки. Інноваційна політика регіону в контексті ринкової економіки є основним інструментом у конкурентній боротьбі, яка створює умови для довгострокового розвитку. Тому саме інноваційній політиці належить провідна роль у формуванні конкурентоспроможності та інвестиційної привабливості регіону $[3$, c. $59-65]$.

Таким чином, на нашу думку, інвестиційна привабливість регіону - це комплекс регіональних умов і результат діяльності та взаємодії всіх сторін інвестиційного процесу (органів влади, у т. ч. регіональних, представників бізнесу, населення тощо), тобто сукупність ознак, що впливають на інтенсифікацію припливу інвестицій у регіон, а як кількісний параметр припливу інвестицій може розглядатися величина інвестиційної активності, що являє собою показник, котрий знаходиться у прямій залежності від величини інвестиційної привабливості. Для підвищення інвестиційної активності в регіоні необхідно:

- підтримувати сприятливий інвестиційний клімат (у довгостроковій перспективі);

- обмежувати державне регулювання інвестиційного процесу;

- стимулювати державно-приватне партнерство;

- підтримувати розвиток інфраструктури, інституційного середовища регіону.

Таблиця 1- Цільові установки управління інвестиційно-інноваційною діяльністю обласної державної адміністрації щодо формування інфраструктури регіону в умовах децентралізації

\begin{tabular}{|c|c|}
\hline Установка & Зміст \\
\hline $\begin{array}{l}\text { 1) Під час реалізації прямої } \\
\text { державної підтримки }\end{array}$ & $\begin{array}{l}\text { В умовах розвиненого інституційного середовища цільовими установками під час реаліза- } \\
\text { ції даного підходу є максимізація ефективності регіонального законодавства щодо взаємодії } \\
\text { органів влади та інвесторів, а також максимізація ефективності використання «жорсткої» } \\
\text { регіональної інфраструктури (цільовий орієнтир інвестиційної політики); за відносно нероз- } \\
\text { виненого інституційного середовища ключові цільові установки - забезпечення фінансової } \\
\text { стійкості регіону і максимізація ефективності використання «жорсткої» регіональної інфра- } \\
\text { структури (цільовий орієнтир інвестиційної політики). }\end{array}$ \\
\hline $\begin{array}{l}\text { 2) Під час формування } \\
\text { механізмів державно- } \\
\text { приватного партнерства }\end{array}$ & $\begin{array}{l}\text { В умовах розвиненого інституційного середовища цільовими установками під час реаліза- } \\
\text { ції даного підходу є розвиток внутрішнього ринку регіону, а також забезпечення інновацій- } \\
\text { ної діяльності трудовими ресурсами (цільовий орієнтир інвестиційної політики); за відносно } \\
\text { нерозвиненого інституційного середовища ключові цільові установки - забезпечення фінансо- } \\
\text { вої стійкості регіону і максимізація ефективності розвитку виробничого потенціалу (цільовий } \\
\text { орієнтир інвестиційної політики). }\end{array}$ \\
\hline $\begin{array}{l}\text { 3) Під час формування } \\
\text { механізмів приватно- } \\
\text { державного партнерства }\end{array}$ & $\begin{array}{l}\text { В умовах розвиненого інституційного середовища цільовими установками під час реалізації } \\
\text { даного підходу є розвиток внутрішнього ринку регіону, а також максимізація ефективності } \\
\text { використання «м'якої» регіональної інфраструктури (цільовий орієнтир інвестиційної полі- } \\
\text { тики); за відносно нерозвиненого інституційного середовища ключові цільові установки - } \\
\text { забезпечення регіональних організацій та підприємств трудовими ресурсами і максимізація } \\
\text { ефективності розвитку виробничого потенціалу (цільовий орієнтир інвестиційної політики). }\end{array}$ \\
\hline $\begin{array}{l}\text { 4) Під час формування } \\
\text { стимулів розвитку } \\
\text { iнновацій для приватних } \\
\text { інвесторів }\end{array}$ & $\begin{array}{l}\text { В умовах розвиненого інституційного середовища цільовими установками під час реалізації } \\
\text { даного підходу є забезпечення регіону природними ресурсами за збереження екологічної без- } \\
\text { пеки, а також максимізація ефективності використання «м'якої» регіональної інфраструктури } \\
\text { (цільовий орієнтир інвестиційної політики); за нерозвиненого інституційного середовища } \\
\text { ключові цільові установки - максимізація ефективності використання «жорсткої» регіональ- } \\
\text { ної інфраструктури і підвищення ефективності регіонального законодавства щодо взаємодії } \\
\text { органів влади та інвесторів (цільовий орієнтир інвестиційної політики). }\end{array}$ \\
\hline
\end{tabular}


Сучасні методи фінансування регіональної інфраструктури свідчать про іiі недостатність та характеризуються низькою якістю обслуговування населення, високою ефективністю використання основних фондів та неефективним управлінням об'єктами. Підхід до управління регіональною інфраструктурою потребує реформування. Словом, нам потрібно залучити додаткові інвестиції, перебудувати іiі структуру та широко реформувати.

Практики управління як в економічно розвинутих країнах, так і в країнах, що розвиваються, свідчать про збільшення активності з використанням різних форм державно-приватного партнерства для підтримки регіональної інфраструктури. «У західній практиці така взаємодія держави та приватного бізнесу отримала назву Public-Private Partnership (PРP), тобто державноприватне партнерствол (ДПП). Предметом такого партнерства $є$ розвиток, використання та управління державною та муніципальною власністю».

«За даними центральних та місцевих органів виконавчої влади в Україні станом на 01.01.2020 на засадах ДПП укладено 187 договорів, з яких реалізується 52 договори (34 - договорів концесії, 16 - договорів про спільну діяльність, 2 - інші договори), 135 договори не реалізується (4 договори - закінчено термін діï, 18 договорів розірвано, 113 договорів не виконуються)». Ці проєкти здійснюються в таких галузях економіки: збір, очищення та розподіл води, будівництво та/або експлуатація автомобільних доріг, доріг, залізниць, злітно-посадкових смуг, мостів, підвищених тунелів та метро, морських та річкових портів та інфраструктури. Більшість концесійних угод охоплює житло та комунальні послуги.

У рамках державно-приватного партнерства Дніпро планує побудувати сміттєпереробний завод. Нині ми шукаємо інвесторів. Орієнтовна вартість проєкту становить 60 млн дол., а термін окупності - 10 років.

«Сьогодні проєктним офісом із питань державноприватного партнерства визначено три пілотні проєкти, у яких планується розпочати процес ДПП. Це будівництво зернового терміналу потужністю 4 млн т на рік та олійно-екстракційного заводу потужністю 0,5 млн т на рік».

Групою компаній «Співдружність» на розгляд Міністерства інфраструктури подано «Пропозицію про здійснення державно-приватного партнерства 3 реалізації проєкту «Модернізація об'єктів портової інфраструктури Херсонського і Скадовського морських торговельних портів і їх ефективного розвитку». Очікується, що до Херсонського порту надійдуть інвестиції у розмірі від 25 до 45 млн доларів» [6, с. 141-150].

В основі теоретичної концепції управління конкурентоспроможністю регіональної економіки на основі застосування ДПП лежить положення про те, що підвищення конкурентоспроможності регіональної економіки сприяє зниження витрат господарюючих суб'єктів, яке досягається на основі розвитку інфраструктурної сфери регіону із застосуванням ДПП (рис. 1).

Відмінною рисою розробленої концепції $\epsilon$ те, що ДПП розглядається в рамках регіональної економіки як комплексне соціально-економічне явище, яке у своїй основі має такі аспекти:

1. ДПП як особлива регіональна соціально-економічна система, що включає у себе такі елементи, як інститути розвитку ДПП, органи влади, приватний бізнес, населення, фінансує організації і наявність певних взаємодій між ними.

2. ДПП як історично зумовлена специфічна форма організації суспільно-господарської діяльності суб'єктів ринкової економіки в умовах іiї переходу до автоматизованого інтелектуального виробництва і зростання частки наукомістких послуг у структурі відтвореного валового національного продукту.

3.ДПП як інструмент, що забезпечує реалізацію регіональної стратегії соціально-економічного розвитку регіону в частині підвищення ефективності функціонування його інфраструктурної сфери.

4. ДПП як проєкт, заснований на об'єднанні зусиль регіональної влади і приватного бізнесу і спрямований на досягнення конкретної мети - надання на регіональному рівні кінцевим споживачам якісно функціонуючого об'єкта інфраструктури. У цьому аспекті йдеться лише про ті проєкти, де взаємодія бізнесу і регіональної влади має довгостроковий, обмежений часом характер і заснована на спільному інвестуванні регіонального бюджету і приватного бізнесу в інфраструктурні об'єкти. При цьому приватна сторона готова вкладати в проєкти власні фінансові та управлінські ресурси на умовах платності, а також заздалегідь обумовленому паритеті взаємних інтересів і ризиків [4, с. 34-39].

Концепція управління конкурентоспроможністю регіональної економіки на основі застосування ДПП спирається на такі принципи:

1. Принцип синергії сторін, що взаємодіють у регіональному проєкті ДПП. Наявність істотних відмінностей у підходах до управління проєктами у регіональній влади і бізнесу збільшує ймовірність виникнення у кожної зі сторін істотних транзакційних витрат, пов'язаних із підготовкою, укладанням та реалізацією угод про ДПП (наприклад, витрати, пов'язані з розробленням конкурсної документації, пошуком оптимальної моделі державно-приватного партнерства, проведенням переговорів із потенційними приватними партнерами, забезпеченням виконання взятих на себе сторонами зобов'язань). У крайньому разі ці витрати можуть навіть нівелювати досягнення позитивного

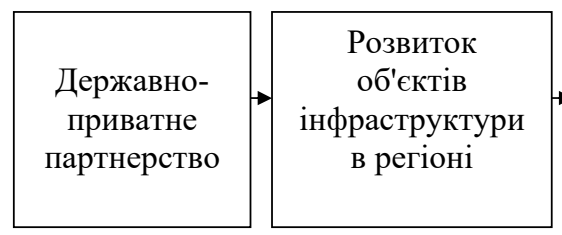
Зниження витрат господарюючих суб'єктів
(логістичні, транзакційні

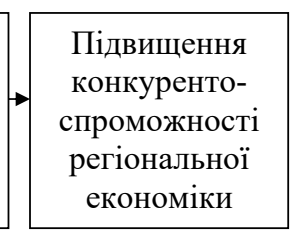

Рисунок 1 - Взаємозв'язок конкурентоспроможності регіональної економіки та державно-приватного партнерства 
синергетичного ефекту, заснованого на взаємному доповненні і збагаченні сторін і полягає в ефективному досягненні цілей регіонального проєкту ДПП (тобто більш короткі терміни, менші витрати і забезпечення кращої якості надаваних на основі використання об'єкта інфраструктури послуг кінцевим споживачам порівняно з варіантом, якби цей проєкт реалізовувала кожна зі сторін самостійно).

При цьому позитивний синергетичний ефект регіонального проєкту ДПП досягається за умови, що сильні боки приватного партнера перекривають слабкі боки регіону, і водночас регіональна влада створює нормативно-правові та політичні (наявність політичної волі) можливості для участі в проєкті приватного партнера, при цьому транзакційні витрати сторін не збільшуються або збільшуються незначно. У цьому разі проєкт буде реалізований ефективно [5, с. 67-70].

2.Принцип комплексної ефективності регіонального проекту ДПП полягає у тому, що підвищення конкурентоспроможності економіки регіону може бути досягнуте за одночасного виконання двох необхідних умов (ефективності для бюджету (порівняння критерію «співвідношення ціни і якості» (valueformoney (VFM) 3 критерієм «бюджетна ефективність при державних закупівлях» (publicsectorcomparator (PSC)) і ефективності для приватної сторони (класичні показники NPV, PI, IRR, PP)) і однієї достатньої умови (отримання соціально-економічного ефекту (критерій - реалізація регіонального проєкту ДПП забезпечує досягнення низки соціально-економічних показників, визначених стратегій соціально-економічного розвитку регіону)).

3.Принцип інноваційності регіональних проєктів ДПП. Аналіз світового досвіду застосування ДПП підтверджує той факт, що ДПП стимулює використання в інфраструктурних проєктах інноваційних технологій значно частіше порівняно з тими випадками, коли йдеться виключно про державні інвестиції, в основі яких лежать державні закупівлі. Ця обставина пов'язана 3 тим, що органи регіональної влади під час вибору приватної сторони фокусуються на чіткому описі критеріїв якості послуги, яка надаватиметься з використанням створюваного інфраструктурного об'єкта, і при цьому не обмежують потенційних приватних партнерів у виборі технологічних рішень, що забезпечують досягнення встановлених критеріїв якості.

4.Принцип інтегрованості ДПП у стратегію соціально-економічного розвитку регіону полягає у тому, що регіональні інфраструктурні проєкти, що реалізуються на основі ДПП, повинні бути чітко взаємопов'язані із цілями затвердженої стратегії соціально-економічного розвитку регіону. При цьому ДПП у жодному разі не має розглядатися виключно як засіб вирішення локальних проблем мікроекономічного масштабу.

Отже, використання ДПП здатне надавати мультиплікативний ефект на регіональну економіку. Реалізація концепції управління конкурентоспроможністю регіональної економіки на основі застосування ДПП залежить від трьох груп ресурсів, які також зумовлюють наявність специфічних рис, що характеризують особливості стану ДПП в окремих регіонах:

- кадровий ресурс полягає в об'єктивній необхідності забезпечення органів регіональної влади кваліфікованим у сфері ДПП персоналом, а також залежить від рівня активності регіональної влади (наявність політичної волі) з ініціювання нових проєктів ДПП;

- інформаційний ресурс залежить від рівня розвиненості інформаційної та методичної підтримки функціонування і розвитку ДПП у регіоні;

- інвестиційний ресурс визначається рівнем інвестиційних можливостей регіону, включаючи наявність у регіону успішного досвіду реалізації проєктів.

Висновки. У результаті проведеного дослідження визначено, що інвестиції спрямовуються або у фізичний капітал, або в людський капітал, або в сектор знань. Визначено зміст цільових установок управління інвестиційно-інноваційною діяльністю обласної державної адміністрації щодо формування інфраструктури регіону в умовах децентралізації: під час реалізації прямої державної підтримки; під час формування механізмів державно-приватного партнерства; під час формування механізмів приватно-державного партнерства; під час формування стимулів розвитку інновацій для приватних інвесторів.

Зазначено, що сучасні методи фінансування регіональної інфраструктури свідчать про іiі недостатність та характеризуються низькою якістю обслуговування населення, високою ефективністю використання основних фондів та неефективним управлінням об'єктами. Потрібно залучити додаткові інвестиції, перебудувати іï структуру та широко реформувати. Практики управління як в економічно розвинутих країнах, так i в країнах, що розвиваються, свідчать про збільшення активності з використанням різних форм державноприватного партнерства для підтримки регіональної інфраструктури.

\section{Список використаних джерел:}

1. Акмаєв А.І. Удосконалення оцінки конкурентоспроможності підприємства в умовах глобалізації. Культура народов Причерноморья. 2007. Вип. 99. С. 7-10.

2. Александрова О.В. Економічна стійкість сільськогосподарського виробництва як основний чинник його конкурентоспроможності. Збірник наукових праџь Таврійського державного агротехнологічного університету. 2012. № 2. Т. 3. С. $13-21$.

3. Алексеенко Н.В. Устойчивое развитие предприятия как фактор экономического роста. Економіка і організація управління. 2008. Вип. 3. С. 59-65.

4. Бугай В.З., Омельченко В.М. Analysisandevaluationoffinancialstabilityoftheenterprise. Держава та регіони. 2008. С. $34-39$.

5. Васильчак С.В. Економічна стійкість сільськогосподарських підприємств: стратегічний менеджмент. Формування ринкових відносин в Україні. 2015. Вип. 6(169). С. 67-70.

6. MykolaKravchenko, SvitlanaKhalatur, KaterynaZhylenko, YuliiaMasiuk, LiudmylaVelychko. Assessment of bank lending diversificationin Ukraine. Banks and Bank Systems. 2018. № 13. P. 141-150. 


\section{References:}

1. Akmaiev A.I. (2007) Udoskonalennia otsinky konkurentospromozhnosti pidpryiemstva v umovakh hlobalizatsii [Improvement of enterprise competitiveness assessment in the conditions of globalization]. Kultura narodov Prychernomoria, vol. 99, pp. 7-10.

2. Aleksandrova O.V. (2012) Ekonomichna stiikist silskohospodarskoho vyrobnytstva yak osnovnyi chynnyk yoho konkurentospromozhnosti [Economic sustainability of agricultural production as a major factor in its competitiveness]. Zbirnyk naukovykh prats Tavriiskoho derzhavnoho ahrotekhnolohichnoho universytetu, no. 2, t. 3, pp. 13-21.

3. Alekseenko N.V. (2008) Ustoichyvoe razvytye predpryiatyia kak faktor эkonomycheskoho rosta [Sustainable development of the enterprise as a factor of economic growth]. Ekonomika i orhanizatsiia upravlinnia: zb. nauk. pr., vol. 3, pp. 59-65.

4. Buhai V.Z., Omelchenko V.M. (2008) Analiz ta otsinka finansovoi stiikosti pidpryiemstva [Analysis and evaluation of financial stability of the enterprise]. Derzhava ta rehiony, no. 1, pp. 34-39.

5. Vasylchak S.V. (2015) Ekonomichna stiikist silskohospodarskykh pidpryiemstv: stratehichnyi menedzhment [Economic sustainability of agricultural enterprises: strategic management]. Formuvannia rynkovykh vidnosyn v Ukraini, vol. 6 (169), pp. 67-70.

6. Mykola Kravchenko, Svitlana Khalatur, Kateryna Zhylenko, Yuliia Masiuk, Liudmyla Velychko (2018) Assessment of bank lending diversi ficationin Ukraine. Banks and Bank Systems, no. 13, pp. 141-150.

Kravchenko Mykola

Dniprovsk State Agrarian-Economic University

\section{TARGET ASPECTS OF INVESTMENT AND INNOVATION MANAGEMENT OF THE DNIPROPETROVSK REGIONAL STATE ADMINISTRATION TO ENSURE THE ECONOMIC SECURITY OF THE MANAGEMENT SOCIETY}

The article substantiates the theoretical, methodological and practical provisions aimed at investment and innovation activities of the Dnipropetrovsk Regional State Administration on the formation of the region's infrastructure in the context of decentralization. In accordance with the above, the theoretical and methodological aspects of investment and innovation activities of the regional state administration on the formation of the region's infrastructure in the context of decentralization were considered; the current state of attracting investments in the development of the region's infrastructure is analyzed; tasks and measures of attraction of investments concerning formation of infrastructure of the region are allocated; the prospects of attracting investments in the development of the region's infrastructure are determined; the target installations of management of investment and innovation activity of the regional state administration concerning formation of infrastructure of the region in the conditions of decentralization are substantiated; public-private partnership is proposed as a tool to attract investment in the development of regional infrastructure; mechanisms for ensuring the development of innovative processes for the formation of the region's infrastructure have been identified. In modern conditions, the impact of destabilizing factors of the external and internal environment is extremely acute, which requires special attention to the study of the problems of strengthening the economic security of the agricultural sector through territorial production systems. The mechanism of interaction between the government and agrarian business in the field of strengthening the economic security of the agricultural sector in foreign countries has been implemented for a long time and is constantly being improved. Socially significant problems, taking into account the growing needs of the population, remain a priority for the mechanism of public-private partnership and are addressed to strengthen the economic security of the agricultural sector. A distinctive feature of the interaction between government and business is how effectively state institutions and management of agrarian business can prevent internal and external threats and eliminate the harmful effects of certain negative components of the external and internal environment. The study is to conduct a detailed scientific and practical substantiation of ways to strengthen the economic security of the agricultural sector with the help of territorial production systems in Ukraine and identify areas for improvement of this sector of the economy.

Key words: agrarian sector, agrarian business, economic security, territorial production systems, integration, agrarian sector.

JEL Classification: E22, E27, M21 